\title{
NEW SOURCES OF BANK FUNDS: CERTIFICATES OF DEPOSIT AND DEBT SECURITIES
}

\author{
George W. McKinnex, JR.*
}

In a free-enterprise economy such as that of the United States it is the vital function of the money and capital markets to allocate the limited supply of savings among the virtually limitless investment opportunities available. Surplus funds are accumulated by some individuals, business firms, public agencies, and other savers; these funds are borrowed by other individuals, business firms, public agencies, and other borrowers for investment in new homes, production facilities, schools and highways, and the like. Financial institutions such as commercial banks, savings and loan associations, and insurance companies serve as intermediaries between savers and borrowers. These financial intermediaries compete for the funds accumulated by savers through both the price and the quality of service they offer. Borrowers compete for funds by means of the interest rate they pay and the degree of security of the loan or investment they provide. It is the economic function of the financial intermediaries to scrutinize each loan or investment opportunity to insure that the funds channeled through them are directed into the investment applications which afford the least risk of loss with the highest prospect of a profitable return on the savers' money invested. In this way the money and capital markets provide a mechanism by which the scarce supply of savings may be channeled into the most productive uses and hence by which economic growth and progress may be maximized.

Financial intermediaries perform other functions which facilitate the flow of savings into investment. By accepting the relatively small accumulations of money from individual savers and making the funds available to meet the relatively large investment needs of borrowers, they provide a diversification of risk which would not be possible if the investment by savers were direct. Since funds deposited in a bank or savings and loan association are backed by all the loans and investments of the bank or association and suitably protected by capital or reserves, failure of a single loan or investment need not result in loss to the individual saver. Further, specializing in the appraisal of loan and investment applications, financial institutions are able to develop a degree of expertise to which most individuals simply cannot aspire. Finally, the pooling of large numbers of small savings accounts affords economies of scale which reduce the borrowers' cost of acquiring funds while at the same time providing profit opportunities to the financial institution.

The optimum allocation of capital afforded by the market and the advantages provided by financial intermediaries can be achieved only if financial institutions are

\footnotetext{
*Vice President and Senior Economist, Irving Trust Company, New York, New York.
} 
free to compete for the scarce funds supplied by savers and if they are free to direct those funds into the most productive lines of investment. Restrictions on the freedom of financial institutions to compete for savings or constraints on their freedom to allocate funds may lead to misallocation of capital resources, increase in the cost of borrowed funds, and a retardation of economic progress.

In competing for the accumulations of savers, financial institutions offer many different kinds of services. In recent years commercial banks have introduced several new types of savings media. Their development of negotiable certificates of deposit (C/Ds), consumer-type time certificates of deposit, and subordinated debt securities has reflected their desire to improve their competitive posture in relation to other types of financial institutions. This was particularly true of metropolitan New York banks, which had found themselves at a competitive disadvantage.

\section{I}

The Development of the Certificate of Deposit

The trend toward generally higher interest rates during the mid-r95os prompted the large national corporations, which traditionally have concentrated their banking activities in New York, to devise methods to economize on cash balances and to maximize income returns on their liquid asset holdings. More rapid growth of corporate activities in the South and West, together with a tendency toward decentralization in corporate operations, resulted in a shift of deposits to regional banks. The large New York banks watched their share of total deposits melt away from some twenty-five per cent of all commercial bank deposits in I94I to less than fifteen per cent in 1960 .

Many of the large New York banks sought to offset this decline in their corporate business by shifting emphasis to retail banking services. Through the establishment of branch offices or through mergers with branch systems the Wall Street banks hoped to reach the general public. State legislation restricting branch and holding company banking tended to frustrate these efforts, however, as retail customers slipped away to the suburbs in ever-increasing numbers.

In these circumstances New York banks began to re-examine their long-standing reluctance to accept and pay interest on time deposits of domestic corporations. In the past they had felt that corporations would seize the opportunity by switching existing funds from demand deposits to interest-bearing time accounts, thus increasing a bank's interest cost without increasing its deposit holdings. Corporate time deposits were expected to behave in a contra-cyclical manner, flowing into the banks during periods of business decline and out during periods of expansion, in contrast to the cyclical pattern of loan demand. Thus the banks would be paying for funds which could be expected to melt away at the very moment when the banks could use them best.

By mid-rg60, however, the combined effect of rapidly rising loan demand and 
restricted deposit growth had pushed the lending capacity of the New York banks very near to current practical limits. The ratio of loans to deposits of those banks amounted to 0.63 as compared to a ratio of less than $0.5^{\mathrm{I}}$ for other banks. This pressure on their lending capacity provoked considerable concern among New York bankers that they might not be able to satisfy the legitimate loan demand of their customers during the next cyclical expansion. Since few banks outside financial centers such as New York are large enough or have lending limits adequate to the needs of large corporate borrowers, this might have in some degree restricted the access of such firms to credit and distorted the allocation of short-term funds in the money and capital markets. This concern prompted considerable thought as to the most appropriate methods for recovering old or attracting new deposits as sources of lendable funds. Selection of corporate time deposits seems to have been influenced by the aggressive bidding for such deposits by foreign, particularly Canadian, banks operating in the United States.

Negotiable time certificates of deposit had been issued by banks in various parts of the country to corporations, state and local governments, foreign investors, and others prior to I $96 \mathrm{r}$. Indeed, the volume of time certificates of deposit outstanding at the end of rg6o exceeded $\$$ i billion. Banks recognized that in order for $C / D$ s to serve as an effective device to attract and hold corporate funds in significant volume, they must be offered at rates competitive with other money market instruments. Moreover, in order to afford the purchaser the same degree of liquidity as other money market instruments, an active secondary market must be assured. The growth of $\mathrm{C} / \mathrm{Ds}$ has been faster because their liquidity has been improved by the creation of a secondary market.

\section{A. Regulation $\mathrm{Q}$}

The development of the negotiable certificate of deposit as an effective money market instrument has hinged very closely on Federal Reserve policy regarding its Regulation Q. Regulation Q imposes ceilings on the interest rates that banks may pay on time deposits of all kinds, including C/Ds. ${ }^{1}$ From time to time, during the new era of the certificate of deposit, these ceilings have prevented banks from competing effectively for short-term funds. As expanding business activity pushes up the demand for funds, the interest rates on other money market instruments are free to respond to the pressure in the market. Banks, too, are free to bid for shortterm funds by raising the rates they pay on $\mathrm{C} / \mathrm{Ds}$ - until they bump up against the ceiling imposed by Regulation Q. At that point not only are banks unable to attract additional funds, they may be faced with a loss of funds as rate-sensitive depositors shift from $\mathrm{C} / \mathrm{Ds}$ to higher yielding instruments. In these circumstances the Federal Reserve has usually recognized the need to insure competitive freedom by revising the regulation to allow the banks to offer $\mathrm{C} / \mathrm{D}$ s at competitive rates.

\footnotetext{
1 I2 C.F.R. $\$ 217.3$ (a) (Supp. I966).
} 
Four such revisions have been made during the six-year history of the C/D. Each has been followed by an upsurge in the volume of certificates outstanding. Tables I and 2 illustrate these developments.

TABLE I

Maximum Interest Rates Payable on Time and Savings Deposits

(Per cent per annum)

(Applicable to All Insured Commercial Banks)

\begin{tabular}{|c|c|c|c|c|c|c|}
\hline \multirow[b]{2}{*}{ Type and Maturity of Deposit } & \multicolumn{6}{|c|}{ Effective Date } \\
\hline & $\underset{1936}{\operatorname{Jan} .1,}$ & $\begin{array}{c}\text { Jan. 1, } \\
1957\end{array}$ & $\underset{1962}{\operatorname{Jan} .1}$ & $\begin{array}{l}\text { July 17, } \\
\text { 19丷63 }\end{array}$ & $\begin{array}{l}\text { Nov. 24, } \\
1964\end{array}$ & $\begin{array}{c}\text { Deo. 6, } \\
1065\end{array}$ \\
\hline 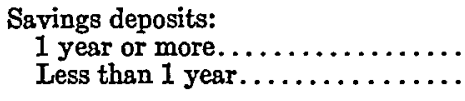 & $\begin{array}{l}2-1 / 2 \\
2-1 / 2\end{array}$ & $\begin{array}{l}3 \\
3\end{array}$ & $\begin{array}{l}4 \\
3-1 / 2\end{array}$ & $\begin{array}{l}4 \\
3-1 / 2\end{array}$ & $\begin{array}{l}4 \\
4\end{array}$ & $\begin{array}{l}4 \\
4\end{array}$ \\
\hline 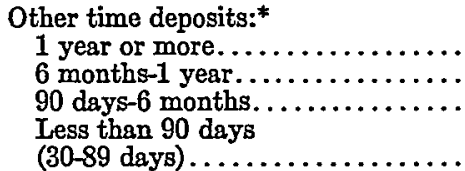 & $\begin{array}{l}2-1 / 2 \\
2-1 / 2 \\
2 \\
1\end{array}$ & $\begin{array}{l}3 \\
3 \\
2-1 / 2 \\
1\end{array}$ & $\begin{array}{l}4 \\
3-1 / 2 \\
2-1 / 2 \\
1\end{array}$ & $\begin{array}{l}4 \\
4 \\
4 \\
1\end{array}$ & $\begin{array}{l}4-1 / 2 \\
4-1 / 2 \\
4-1 / 2 \\
4\end{array}$ & $\begin{array}{l}5-1 / 2 \\
5-1 / 2 \\
5-1 / 2 \\
5-1 / 2\end{array}$ \\
\hline
\end{tabular}

*Effective July 20, 1966, the Board reduced the maximum rate that member banks may pay from 5-1/2 to $5 \%$ on now multiple-maturity depesits of 90 days or more and from 5-1/2 to $4 \%$ on new multiple-maturity deposits of less than 00 days. On Soptsmber 20, 1000 the ceiling rate on single maturity deposits of less than $\$ 100,000$ was reduced to $5 \%$. The FDIC, acting with respect to nonmember insured banks as well, effected the same changes as the Board.

Source of data: Board of Governors of the Federal Reserve System.

TABLE 2

Outstanding Negotiable Time Certificates of Deposit, Annualix, xg60-xg65

\begin{tabular}{|c|c|}
\hline Date & Volume in Billions of Dollars \\
\hline 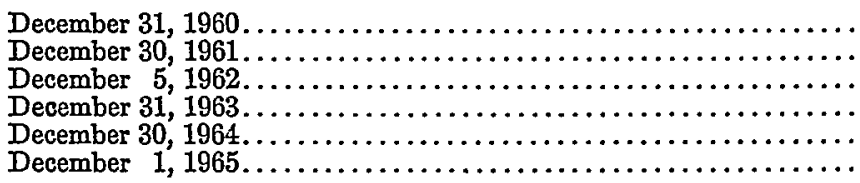 & $\begin{array}{r}1.1 \\
3.2 \\
6.2 \\
9.6 \\
12.6 \\
16.5\end{array}$ \\
\hline
\end{tabular}

Source of data: Board of Governars of the Federal Reserve System.

The first efforts to promote negotiable C/Ds were made by several large New York banks early in 196r. At that time maximum allowable rates were one per cent for time deposits of less than ninety-day maturity; two and a half per cent for maturities of ninety days to six months; and three per cent for six months or more. These ceilings were sufficiently liberal to allow the banks to offer attractive rates, and the volume of $\mathrm{C} / \mathrm{D}$ s rose to $\$ 3.2$ billion over the year. By the end of the year, however, the upward march of interest rates associated with expanding business activity had pushed rates on six-month Treasury bills to three per cent, and further development of $\mathrm{C} / \mathrm{Ds}$ became thwarted.

On January I, Ig62, the Federal Reserve raised the permissible rate on time deposits of over six months' maturity. For certificates having a maturity of six 
months to one year the rate was raised to three and a half per cent; for those of longer than one-year maturity, the maximum rate was boosted to four per cent. For maturities of less than six months, rates remained unchanged. This revision enabled banks to compete for the longer maturities but denied them direct access to funds seeking shorter maturities. Despite this constraint, the dollar volume of certificates of deposit jumped to over $\$ 6$ billion by the end of rg62. This represented a quite remarkable annual growth of 93.7 per cent.

Banks continued to be seriously impeded in selling new certificates with original maturities of less than six months. The ceiling rate of two and a half per cent became increasingly restrictive as rates on other instruments rose. However, on July $\mathrm{I}_{7}, \mathrm{rg}_{3}$, the ceiling rate on maturities from ninety days to one year was pushed up to four per cent. Continuance of the very low one per cent for maturities of thirty to eighty-nine days virtually barred banks from issuing certificates in that shortest maturity range. The growth in dollar volume of $\mathrm{C} / \mathrm{Ds}$ was even greater in 1963 than in the previous year but, due to the enlarged base, amounted to a smaller, though by no means unimpressive, relative increase of 54.7 per cent.

Both the dollar amount and the relative rate of growth in $C / D$ volume were lower in 1964 than in the preceding year. Much of this more limited increase took place early in the year, and as general market rates increased over the year the banks' ability to compete for interest-sensitive short-term funds with the Treasury bill, finance-company paper, and other market media tended to wane. It was not until November that another relaxation of Regulation Q, which permitted a dramatic rise in the permissible rate on thirty- to eighty-nine-day certificates from one to four per cent and a complementary increase on longer maturities from four to four and a half per cent, allowed the commercial banks to come back strongly into the money market. Much of the benefit to commercial banks of this revision was experienced in the following year. The dollar volume of $\mathrm{C} / \mathrm{Ds}$ registered an expansion of $\$ 3.9$ billion, the largest dollar increase of any year since the advent of the certificate as an important banking device. Due to the greatly expanded base this represented only a thirty-one per cent relative increase.

In the last quarter of 1965 the continued rise of market interest rates impelled yet another increase in permissible rates. The December 1965 revision represented the most sizable upward shift in the brief history of $\mathrm{C} / \mathrm{Ds}$. Maximum rates on time deposits were set at five and a half per cent on all maturities over thirty days. The increase, however, did not apply to savings accounts. Since maximum rates payable on savings accounts were kept at four per cent, commercial banks were only able to compete effectively for savings funds with savings and loan associations, mutual savings banks, and other savings institutions, and with open market instruments, savings bonds, and other investment media, by developing and promoting "consumertype" certificates, usually nonnegotiable and of small denominations. Congressional concern for the impact of tight money on the housing industry led to the passage 
of legislation which affirmed the authority of the Federal Reserve to establish discriminatory ceilings on various types of deposits, and maximum rates on these consumer-type C/Ds were lowered to five per cent. At this level commercial banks could not compete effectively with market instruments, nor with some savings-type institutions. Individuals' funds were attracted in large volume to market instruments. The flow of savings into savings institutions and into commercial bank savings accounts (plus consumer-type C/Ds) slowed sharply in 1966 . The growth of consumer funds in commercial banks was slowed relatively more than in savingstype institutions.

By the third quarter of 1966 an increasingly restrictive monetary policy had pushed money market rates to new high levels. The rate on Treasury bills reached $5 \%$ per cent and the rate on ninety-day sales finance company paper rose to $5 \%$ per cent. At these rates, large certificates of deposits were no longer competitive. (Corporate treasurers tend to shift out of $C / D$ s into Treasury bills if the $C / D$ rate is less than $1 / 4$ percentage point above the bill rate, and they will frequently buy finance-company paper if they can get an extra $1 / 8$ point or $1 / 4$ point above the $C / D$ rate.) Since money market instruments are hotly competitive, there was a rapid attrition of C/Ds. The national total of outstanding C/Ds declined from \$18.6 billion in August to \$15.4 billion in December. The decline at large New York City banks was at a faster rate, since these are money market banks which handle the most sensitive shortterm funds. The decline there was nearly twenty-nine per cent in four months.

Some relaxation of monetary policy restraints permitted an easing of the rate structure in the last months of 1966 . Bill rates and other short-term rates declined to levels which permitted commercial banks to compete for funds within the ceiling prescribed by the Federal Reserve. By the end of December the attrition was reversed.

The six-year experience with negotiable certificates of deposit reflects dramatic but irregular growth. C/Ds have emerged from their relatively insignificant role to become a major short-term money market instrument. From $\$ \mathrm{I}$ billion in 1960 the dollar volume of $C / D$ s grew to more than $\$ 18$ billion in $x 966$. The irregular nature of this experience has resulted from the starts and stops imposed by Federal Reserve policy toward Regulation $Q$. When banks have been free to compete in the market, they have done so effectively. When interest rate ceilings imposed constraints, banks have been denied access to short-term funds.

The rapid early development of the certificate of deposit instrument was facilitated by Federal Reserve policy. In addition to the revisions of Regulation $Q$ which allowed banks effectively to compete for funds, the Federal Reserve has contributed through its over-all approach to monetary policy. For several years, economic conditions during the new era of the certificate of deposit did not require a particularly restrictive monetary policy. Indeed, the Federal Reserve was able to pursue a positively easy monetary policy for a considerably longer period following the $196 \mathrm{I}$ recession than in earlier periods. This easy money policy contributed im- 
portantly to relatively low levels of interest rates on Treasury bills and other money market instruments competitive with C/Ds. In I965 and I966, Federal Reserve policy shifted to one of greater restraint, which in conjunction with rigid rate ceilings effectively forced commercial banks out of competition for many kinds of funds. Late in 1966 these policies were reversed to offset slowing of economic activity.

In addition to the permissive policy of the Federal Reserve, several other factors favored the rapid early development of the C/D. One was the expansion in business revenues as economic conditions improved after rg6r. Another was the changes in tax policy which provided accelerated depreciation allowances and the investment tax credit. These developments augmented corporate cash flow, enlarged liquid asset holdings, and made available substantial flows of funds for investment in C/Ds. A major inducement to the rapid growth of the certificate of deposit was the early emergence of an active secondary market for $\mathrm{C} / \mathrm{Ds}$.

\section{B. The Marketability of $\mathrm{C} / \mathrm{Ds}$}

While time certificates of deposit had been issued by banks prior to $\mathrm{I} 96 \mathrm{r}$, such instruments, even when negotiable in form (which they generally were not), enjoyed only very limited marketability. Thus they could not compete directly with Treasury bills, other short-term Government securities, commercial paper, and other money market instruments. Provision of competitive rate ceilings under Regulation $Q$ and active promotion by commercial banks offered the promise of imparting to $C / D$ s a significant role as a money market instrument which would allow the banks to retain existing deposits and attract new funds. This promise could be fulfilled, however, only if holders of $\mathrm{C} / \mathrm{Ds}$ could be assured of liquidity comparable to that afforded to holders of other money market instruments. The very active markets for most of these other instruments insure that the holder can convert them into cash at virtually a moment's notice. The lack of a secondary market for $\mathrm{C} / \mathrm{D}$ s inhibited their marketability and thus rendered them a relatively illiquid investment instrument. It was clear that in order for $\mathrm{C} / \mathrm{Ds}$ to serve as a device for recapturing the liquid funds of large corporations their marketability would have to be enhanced.

In February Ig6x, when the New York banks made their first efforts to promote $\mathrm{C} / \mathrm{Ds}$, the Discount Corporation, a major Government bond dealer, agreed to "make a market" in the certificates. By the end of I96r several large Government securities dealers were regularly taking positions in the secondary market for C/Ds. Their willingness to buy and sell outstanding certificates provided the ready market and hence high liquidity necessary to make certificates an attractive money market instrument.

Reliance on dealers rather than on the banks themselves to make a market for time certificates of deposit grew out of the regulations of bank supervisory authorities. If issuing banks had sought to make a market for their own $\mathrm{C} / \mathrm{D}$ s by standing willing to repurchase them prior to maturity, the deposits involved might have 
been regarded as demand deposits (on which payment of interest is prohibited ${ }^{2}$ ). On the other hand, had issuing banks endeavored to provide liquidity for their C/Ds by offering to make loans against them, they would have been required to conform with the provision of Regulation $Q$ which requires that loans against time funds bear an interest rate at least two percentage points above that paid on the certificates. ${ }^{3}$ Hence it was necessary to depend upon a nonbank agency to provide the marketability essential if $C / D$ s were to provide an attractive short-term investment for business corporations.

\section{The Issuing Banks}

Banks have issued C/Ds in response to a variety of motives. The primary reason, of course, is to expand the bank's lending capabilities. A second motive has been to reduce the bank's deposit volatility by imposing a definite time commitment on such funds. The relative importance of these motives has varied among the banks issuing $\mathrm{C} / \mathrm{Ds}$. Both motives are served by the retention of funds that otherwise would have been lost and by attracting new funds.

Commercial banks regard the $\mathrm{C} / \mathrm{D}$ as a means of acquiring new deposits. Often banks wish to attract new funds not only in order to secure additional lendable funds, but also as a source of new liquidity. Purchased liquidity acquired to meet deposit withdrawals and other requirements for cash may be less expensive than stored liquidity in the form of secondary reserve assets. From 1962 to 1966 , Regulation $Q$ ceilings were generally high enough to permit prime-name banks to purchase liquidity in large quantities immediately when needed. However, for short periods the Federal Reserve, by delaying upward revision of Regulation $Q$ despite rising interest rates, has caused considerable consternation among banks with large amounts of imminently maturing $\mathrm{C} / \mathrm{Ds}$ outstanding. Illustrations of such circumstances occurred in late November and early December of 1965 , when heavy seasonal loan demands added to the liquidity problems of these banks, and again in 1966 , when ceilings were held rigid in the face of rising market rates. Uncertainty as to the character, magnitude, and timing of ceiling rate changes by the Federal Reserve contributed to development of another relatively new innovation of bank liquidity managementthe short-term open-market note-which will be considered later.

Efforts to promote the sale of negotiable certificates of deposit have been directed largely toward corporate customers. By December 1962, eighty per cent of the certificates in denominations of $\$ 100,000$ or more generated by the twenty largest issuing banks had been sold to business firms. More than half of such certificates issued by medium-sized banks were originally taken by business firms. Among smaller banks issuing certificates in denominations of $\$ 100,000$ or more, business firms were matched in importance by state and local governments.

\footnotetext{
${ }^{2} \times 2$ C.F.R. $\$ 2 \times 7.2\left(I_{963}\right)$.

Id. $\$ 217 \cdot 4(\mathrm{e})$.
} 
A 1964 survey by the American Bankers Association confirms this preponderance of business organizations as purchasers of negotiable certificates of deposit. Of certificates in the denomination of $\$ 100,000$ to $\$ 500,000$, forty-six per cent had been taken by business and twenty-three per cent by state and local governments. Certificates in the larger denominations, $\$ 500,000$ and over, had been sold to business firms (nearly seventy per cent) or to foreign governments, banks, and so forth (nearly fourteen per cent).

The large New York money market banks have been the principal sellers of negotiable certificates of deposit. By July 1965 , about forty-five per cent of the approximately \$I billion of negotiable certificates outstanding represented issues of banks in the New York Federal Reserve District. Somewhat less than fifteen per cent had been issued by banks in the Chicago District. The San Francisco District ranked third with just over ten per cent. Banks in the Dallas District, some of which had issued certificates of deposit in both negotiable and nonnegotiable forms long before I96I, accounted for less than eight per cent of the total volume of negotiable certificates of deposit outstanding in mid-rg64. The Cleveland Federal Reserve District was close behind, but each of the other districts accounted for less than five per cent. ${ }^{5}$ This ranking of the participation of the banks in the various districts had not changed appreciably by mid-1966. In all districts it has been banks with relatively low proportions of regular savings to total time deposits which have promoted negotiable certificates of deposit most actively. Generally speaking, these are metropolitan rather than country banks.

D. The Secondary Market

The secondary market which has developed has reached a volume of trading sufficiently broad to impart substantial liquidity to certificates of deposit. During the first nine months following the Discount Corporation's announcement that it would make a market in such instruments the volume of trading amounted to some $\$ 800$ million. By November 1963 , dealers were carrying about $\$ 200$ million in their trading positions, and their inventories of certificates of deposit were clearly on the rise. With continued cultivation of the market by the larger dealers and with the expansion in the number of regular dealers, the average daily trading volume reached a level of about $\$ 60$ million in 1965 . Trading in short-term U.S. Government securities, which that year averaged \$r.5 billion daily, naturally dwarfed activity in all private money market securities, but the volume of activity in certificates of deposit was quite impressive in relation to that in other money market instruments emanating from private institutions.

Even though the certificate of deposit market is now broad enough to provide

\footnotetext{
"Savings Division, American Bankers Ass'n, Results of 1964 Survey of Certificates of Deposit and Savings Certificates 20 ( 1965$)$.

'Brandt, Negotiable C/Ds: Still Not Too Popular At Large District Banks, Fed. Reserve Bank of Atlanta Monthly Rev., Aug. 1964, at 5.
} 
considerable liquidity, most large corporations holding certificates appear to prefer liquidation of short-term Governments to sale of certificates in order to replenish cash funds in time of need. Indeed, many large corporations usually hold their certificates to maturity and seldom, if ever, take advantage of the secondary market. Nevertheless, they value the liquidity which their certificate holdings afford. On the other hand, some corporations as well as holders of other types participate in the secondary market for certificates of deposit in quest of profits as well as to effect adjustments in their cash positions.

The secondary market is largely confined to certificates issued in denominations of $\$ \mathrm{I}$ million or more. Most dealers discourage transactions in certificates of less than \$I million. Issues of other than "prime-name" banks usually sell at rates from five to twenty-five basis points above those of comparable maturities of prime-name banks. There is virtually no secondary market for certificates of most strictly regional banks, even though the certificates are negotiable in form. Such banks have sought to rectify this by acting as agents for holders in selling their certificates of deposit directly to other small investors, thus bypassing the secondary market.

In the early years of the secondary market, the significant differences in interest rate ceilings allowed on various maturities provided holders of $\mathrm{C} / \mathrm{Ds}$ with opportunities for trading profits. For example, prior to November 24, 1964, certificates having a maturity of ninety days or more could pay four per cent. Certificates with original maturities of less than ninety days could pay only one per cent. However, the mere passage of time would "age" the longer maturity: after ninety-one days or more the I80-day C/D has less than ninety days to maturity. Holders of short-term funds seeking an investment instrument with a maturity of less than ninety days would vastly prefer an "aged" $C / D$ of longer original maturity which paid four per cent to a new C/D paying only one per cent. Their demand bid up the price of "aged" C/Ds. This higher market price reduced the yield to less than four per cent, but as long as the yield was greater than one per cent, the "aged" C/D was preferable to a new one. By purchasing a I80-day $\mathrm{C} / \mathrm{D}$, holding it until it had been aged to less than ninety days and then selling it, the investor could obtain not only the four per cent rate during the period he held the certificate but also the profit which resulted from the price increase produced by the bidding of shorter-term investors. This maneuver by corporations and dealers seeking trading profits (known as "riding the yield curve") enabled banks to tap funds in the shorter maturity ranges indirectly, despite the fact that Regulation $\mathrm{Q}$ ceiling rates blocked direct bank competition for such funds.

The gradual transition to a single ceiling rate of interest for all maturities under Regulation Q, in conjunction with rising market rates during 1965 and 1966 , reduced the opportunity for trading profit on certificates of deposit but permitted commercial banks to pay competitive rates on short maturities. It also resulted in a shortening in the average maturity of outstanding certificates, particularly in de- 
nominations of $\$ 100,000$ or more. While in December 1962 , the average maturity of such certificates was in excess of six months, by June Ig66 it had been reduced to 3.7 months. Almost three-fourths of such certificates at that time were to mature within five months. Average maturities were reduced even further as market conditions in late 1966 made the issuance of new C/Ds very difficult.

Despite their role as issuers of certificates of deposit and despite their obvious dependence upon a strong secondary market for them, money market banks have been reluctant to participate in the secondary market as dealers. Anticipating an unfavorable reaction in the banking industry, in other business circles, and particularly in bank supervisory quarters regarding one large bank's holding paper representing very considerable deposits in another large, perhaps directly competing, bank, the money market banks left dealing in the secondary market entirely to nonbank security dealers. However, aggressive bidding for time deposits by the major issuing banks in 1965 boosted interest rates on new certificates to levels which tended to reduce the incentive for resale activities by certificate holders. The resulting decline in the volume of trading activity threatened to jeopardize the effectiveness of the secondary market as a means of assuring liquidity to the certificate of deposit instrument. In order to bolster the operations of the secondary market several large New York banks have entered the certificate of deposit resale market. This increase in the number of dealers may be expected to sharpen quotations and enhance trading activity.

The relatively strong secondary market for negotiable time deposit certificates which has developed in the United States has been of particular importance in restoring the ability of the commercial banks to compete actively for savings. By imparting an appreciable degree of liquidity to, and offering the possibility of capital gains on, negotiable time deposit certificates, the secondary market enhances the attractiveness of the instrument to individuals, business corporations, state and local governments, and other investors. The presence of a reasonably active secondary market for certificates of deposit thus has refashioned the competitive posture of the commercial banks in their struggle to attract and to retain savings.

\section{E. Consumer Time Deposits}

While the large denomination certificate of deposit has received most of the attention and interest of the financial community, it should not be inferred that it is the only type of time deposit that has contributed to the competitive position of commercial banks. For many banks the principal source of additional funds in recent years has been in consumer-type time certificates of deposit. Indeed, in terms of number of banks, these types of deposits are more important than large denomination negotiable certificates. In 1966, as Table 3 indicates, 842 insured banks had issued certificates of deposit of over \$100,000, but nearly 7,000 had some form of consumer-type time deposits and more than $r$,, 000 held the traditional savings 
Law and Contemporary Problems

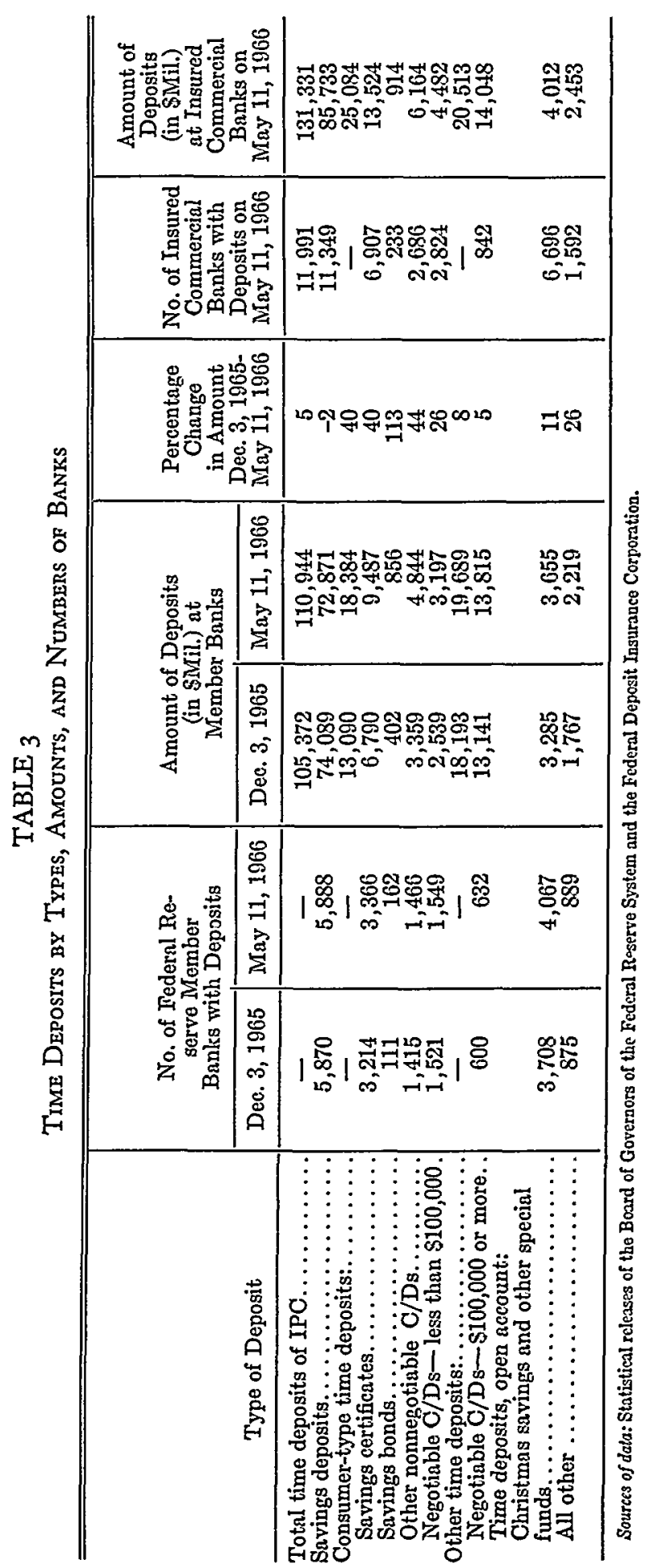


deposits. Thus for most banks consumer-type time deposits and savings accounts are more important than large negotiable $\mathrm{C} / \mathrm{Ds}$.

Consumer-type time deposits include a number of instruments. The four principal devices include savings certificates, savings "bonds" (generally the same as savings certificates except for the name), nonnegotiable certificates of deposit, and negotiable certificates of deposit of less than $\$ 100,000$ denomination. In terms of dollar volume and numbers of banks employing them, savings certificates provide the major instrument. As is shown in Table 3, such deposits in 1966 amounted to $\$$ r.5 billion and involved nearly 7,000 banks. Nonnegotiable certificates of deposit contributed over $\$ 6$ billion to more than 2,500 banks. Negotiable certificates under $\$ 100,000$ produced just under $\$ 4.5$ billion for 2,800 banks. Savings bonds were of far less significance as a means of acquiring customers' time deposits, yielding less than \$I billion for 233 banks. This may be compared with the $\$ 85.7$ billion in savings accounts at more than II,000 banks.

Though time deposits other than savings accounts have long been available at commercial banks, bankers did not push these other types of deposits because they believed that savings deposits enjoyed a lower volatility. In some sections of the country, however, particularly the Midwest and Southwest, these other types of deposits have long played a significant role. Since the early x 960 s the increased sensitivity of many individuals to interest differentials, together with the desire of banks to enlarge their deposit volume, have imparted a far more important role to such types of deposit. For example, at member banks in the Chicago Federal Reserve District, personal certificates of deposit and corporate certificates of deposit have shown approximately the same growth since $1962-$ a much faster growth rate than that of savings accounts.

A great stimulus to consumer-type time deposits as opposed to savings deposits in 1966 was provided by revisions in Regulation Q. ${ }^{6}$ The December 1965 revision left the ceiling rate on savings deposits at four per cent while elevating that on other types of time deposits to five and a half per cent. This differential of one and a half percentage points meant that depositors could increase their interest income by more than one-third by shifting their funds from savings accounts to time accounts (in a bank paying maximum rates). The result was a shift of savings deposits into time deposit instruments and, more importantly, the movement of new funds into such accounts. This is illustrated in Table 3 by the decline in savings accounts in the face of massive increases in consumer-type time deposits in the first half of 1966 . Thus while Federal Reserve member banks were losing more than $\$ \mathrm{x}$ billion in savings deposits, they were registering a gain of more than $\$ 5$ billion in consumertype time accounts. This growth was stimulated chiefly by the higher rates of interest available on such deposits.

${ }^{\circ} 30$ Fed. Reg. 15286 (1965). 
In raising rates to attract funds into these other types of time deposits banks may well have been competing with themselves. Federal Reserve statistics on time deposit growth in 1966 indicate that the banks which were most successful in attracting such funds were also the banks that experienced the sharpest declines in their savings accounts. As the Federal Reserve Bank of New York commented:

Such a finding suggests that some of the funds destined for consumer-type time deposits would otherwise have been lodged in savings accounts; thus, in numerous cases, banks may have been competing to some extent with themselves for these funds. ${ }^{7}$

The effectiveness of a given increase in interest rates to attract and retain deposits has varied considerably at different banks. It appears to depend on the competitive environment of the trade area the bank serves and the geographical region in which the bank is located. Up to the present time, member banks have not been particularly selective regarding the minimum denomination or maturity of the consumers' time deposit instrument which qualifies for the maximum interest rate paid.

Of the four types of consumer time deposit instruments, the nonnegotiable savings certificate has been the most popular. These certificates, which account for more than half of all consumer-type time deposits at commercial banks, increased by just over $\$ 2.5$ billion or some forty per cent in less than half a year in rg66. While other types such as savings bonds showed greater relative increase, their contribution in dollar terms was far less. Nonnegotiable savings certificates ordinarily have an initial maturity of at least six months and often are automatically renewable. Automatic renewal is provided, for example, if the certificate is not redeemed within thirty days after initial maturity. This factor enhances the appeal of the certificate to savers. A recent ruling of the Federal Reserve has generated considerable uncertainty regarding the future growth potential of the automatically renewable savings certificate. In mid-July 1966, the Board of Governors restricted the maximum interest rate to five per cent on "multiple maturities" of ninety days or more and to four per cent on "multiple maturities" of less than ninety days. ${ }^{8}$ The five and a half per cent ceiling on other nonsavings type time deposits was not affected. In September 1966 the ceiling rate on fixed maturity deposits less than $\$ 100,000$ was lowered to five per cent. $^{9}$

II

\section{The Development of Debt Securities}

Despite the success which commercial banks have enjoyed in their use of various time deposit devices to attract and retain funds, a number of considerations have

${ }^{7}$ Recent Banking and Monetary Developments, Fed. Reserve Bank of NEv York Monthly Rev, Aug. I966, at I79, I8x.

3I Fed. Reg. I0022 (I966).

Id. at 12676 . 
led them to explore and develop other possibilities for the attraction of savings. We have noted in preceding pages some of the problems inherent in time deposit banking. Legislation restricting banks' use of $\mathrm{C} / \mathrm{D}$ s and the consumer-type devices would inhibit the further growth of time deposits. Moreover, as a consequence of tight money and high interest rates there developed in 1966 a (no doubt temporary) tendency for savers to bypass financial institutions of all sorts, banks included, and invest their funds directly in the money and capital markets. In the context of the liquidity squeeze, particularly, these considerations prompted commercial banks to move toward debt-security financing for the additional funds to meet the credit demands placed upon them.

The sale of debentures provides banks an additional source of loanable and investable funds. More importantly, however, since such securities are issued in subordinated form, they provide a source of new capital as well. Indeed, it is in situations where banks need an addition to their capital base, to support current or potential deposit growth, that debt security offers the greatest profit prospects to banks. Here a substantial leverage effect is possible since the funds acquired provide not only a source of additional income when loaned or invested but also provide a base for the acquisition of new deposits which may also be converted into earning assets.

Whether or not additional capital is needed, debenture funds are profitable if their total cost to the bank is less than the earnings attributable to them. While need for additional capital seems to have been the primary reason or at least a major reason for most bank debenture issues, it has been speculated that their issuance as a source of investable funds could eclipse their use as a capital raising device. Such a use would represent a sharp break with their historic role.

The sale of debentures by commercial banks is a relatively recent development. Before 1933, banks relied upon common stock and retained earnings for capital funds. Indeed, neither national nor state bank legislation authorized the issuance of either preferred stock or debt securities.

Resort to senior securities for the provision of capital was a development first associated with the Great Depression of the 1930s. With the massive deterioration of general economic conditions in 1930 and 1931, bank failures rose sharply from an average of around 600 per year during the r920s to 1,345 in 1930 and almost 2,300 in 193r. The wave of bank failures mounted as the abrupt decline in asset values ate into and ultimately consumed capital accounts leaving banks unable to meet their deposit obligations. In 1932, Congress created the Reconstruction Finance Corporation (RFC) $;^{10}$ one of the corporation's main objectives was to render financial assistance to banks in difficulties.

The RFC was authorized only to make loans secured by the loans and securities of

\footnotetext{
${ }^{10}$ Reconstruction Finance Corporation Act, ch. 8, 47 Stat. 5 (1932).
} 
the borrowing banks. Despite this aid, banks continued to fail as loan and securities values collapsed and destroyed banks' capital. To further increase the lending power of the RFC, the Emergency Banking Act of 1933 authorized it to make additional loans to banks and to accept their preferred stock as security. ${ }^{11}$ Since some states permitted issuance of preferred stock only if it carried double liability, the RFC later was authorized to purchase subordinated debentures of banks in those states. ${ }^{12}$ Other states exempted banks' preferred stock from the double liability feature in order to facilitate the sale of preferred stock to the RFC. Between March I933 and December 1937, more than 2,000 national banks issued preferred stock and debentures aggregating $\$ 565$ million of which $\$ 499$ million was purchased by the RFC. All told, more than 7,00o banks sold senior securities to the corporation between I933 and I943. The capital thus provided amounted to over \$r.I billion and represented almost one-sixth of the total capital of operating banks in mid-1933.

The substantial volume of senior securities in the capital structure of the nation's banks did not long remain outstanding. With the return of somewhat better business conditions, banks were quick to retire their outstanding debt securities. Bankers generally felt at that time that the presence of debt securities and preferred stock in the capital structure was an indication of financial weakness, a sign that they had been forced into distress financing to remain solvent. The adverse connotation of senior securities in a bank's capital structure prompted their early redemption. This was facilitated by the RFC requirement that bank earnings be retained in a surplus account and not be distributed as dividends. By 1937, nearly half of the issues of national banks had been retired. This retirement continued throughout the remainder of the I930s and during the Second World War, so that at the end of 1945 only $\$ 53$ million of preferred stock and $\$ 43$ million of capital notes and debentures remained outstanding at all insured banks. By the end of I96r, preferred stock had been reduced to $\$ 4.7$ million and capital notes and debentures to \$22.I million out of an aggregate capitalization of \$22.I billion for all insured banks.

Some bankers recognized the advantages of senior securities and sought to retain them as part of their permanent capital structure. However, when they endeavored to secure authorization to replace their RFC issues with new issues sold to private investors, bank supervisory authorities generally denied the request if common stock could be sold instead. Common stock was still regarded as the normal source for bank capital funds. Only the states of New York and New Jersey permitted refinancing of RFC issues by sale of senior securities to private investors. Hence between the mid-1930s and 1963 most new senior securities of commercial banks were issued by state-chartered banks in those two states.

Until quite recently, the brief history of debenture financing by American banks

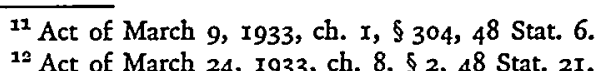


had been dominated by the adverse attitude of bank regulatory authorities. Both the Federal Reserve and the Comptroller of the Currency expressed views hostile to the use of senior securities as sources of bank capital. In this they were followed by state supervisory authorities other than those of New York and New Jersey.

Reluctance on the part of the Board of Governors to regard subordinated debentures as bank capital rather than long-term liabilities dates as far back as I933 when the matter first was raised. In considering the question of permitting a New York state bank with debentures in its capital structure to join the Federal Reserve System, the Board observed that the term "capital" as used in the Federal Reserve Act "shall mean the amount of unimpaired common stock plus the amount of preferred stock outstanding and unimpaired."13 Specifically the Board noted,

$[\mathrm{T}]$ he eligibility of a State bank for membership in the Federal Reserve System depends upon the amount of its capital stock and cannot be determined upon the basis of its capital stock plus borrowed money obtained through the issuance of debentures .... ${ }^{14}$

Some twenty years later, the same question was again brought before the Board. In its decision of August 15, r952, the Board ruled,

Such notes do not come within the definition of the terms "capital" and "capital stock" in section I of the Board's Regulation H, Membership of State Banking Institutions in the Federal Reserve System, and cannot be considered capital for the purposes of membership in the Federal Reserve System under the provisions of section 9 of the Federal Reserve Act. ${ }^{15}$

In not allowing a state member bank to replace preferred stock with debentures, the Board of Governors ruled that there was no urgency in the situation which would warrant the substitution of a long-term loan for any portion of the equity capital in a state member bank. Furthermore, the Board of Governors "did not look with favor on the increasing tendency of banks to turn to capital notes and debentures as a means of augmenting the protection afforded to depositors." ${ }^{16}$ The Board argued,

While borrowed money seems more attractive than the sale of additional equity capital in times of high earnings and high taxes, it can involve a dangerous drain on the earnings of a bank in times of adversity. Furthermore, once a bank embraces the device of borrowed money and affords it priority over existing preferred and common stock, the sale of additional stock becomes extremely difficult, if not impossible. ${ }^{17}$

Over a long period of time, the Board of Governors of the Federal Reserve System thus has consistently taken the position that: (I) debentures are not capital from the viewpoint of the Federal Reserve Act; (2) debentures may involve a considerable

\footnotetext{
${ }^{13}$ Ig Fed. Reserve BuLl. 567 (1933).

${ }^{14}$ Id.

1539 Board of Governors of the Federal Reserve Systems Ann. Rep. 85 (1952).

${ }^{10}$ Id.

${ }^{17} \mathrm{Id}$. at $85-86$.
} 
risk to the issuing bank in periods of low earnings; and (3) the additional financial risk of placing debentures before common stock as a claim on earnings will make the sale of additional common stock difficult.

In the past, the Comptroller of the Currency took a similar position. In 1957, in testimony before a subcommittee of the Committee on Banking and Currency, he took the position that resort to preferred stock or debentures as a usual method of raising capital would result in disproportionate capital structures for most banks. The public interest would be endangered where large amounts of capital in the form of preferred stock and debentures could be manipulated by a thin layer of common stock. He also held as follows:

The increased weight of risk of an enlarged volume of business predicated on newly acquired preferred capital would rest in the first instance on common shareholders. ... O Over a period of time this would result, in our opinion, in the common stock of banks losing some and perhaps much of its present high standing as a sound investment. 18

The Comptroller noted that national banks had raised over \$1 billion of new capital in the years $x 947$ through $x 957$ by issuing common stock. Thus common stock provided a completely adequate means for raising new capital under normal conditions. Regarding debentures, he declared,

The sale of such notes or debentures, in our opinion, would cause the common capital stock of some and perhaps many national banks to lose its attractiveness as an investment because of the adverse leverage of risk brought about by enlarged asset structures based on funds realized from the sale of the notes or debentures. ${ }^{10}$

While the bank supervisory authorities were pursuing this negative attitude toward the use of senior securities, bankers themselves were inclined to recognize debentures and preferred stock as a means of securing flexibility in meeting capital requirements. In the same hearings, Mr. Gibbs Lyons, Past President of the National Bank Division of the American Bankers Association, stated,

The American Bankers Association approves the authority to issue preferred stock on a nonemergency basis with the approval of the Comptroller of the Currency contained in section 20 and also the authority on the same basis to issue capital notes and debentures incorporated in section 2I [of the proposed Financial Institutions Act]. National banks should have greater flexibility in meeting their capital requirements. At certain times it may be preferable to obtain capital by other means than by increasing common stock. These sections would permit capital expansion by means of preferred stock or capital notes and debentures if warranted. ${ }^{20}$

Mr. Sam M. Fleming, appearing as spokesman for the Association of Reserve City Bankers, expressed similar views:

\footnotetext{
${ }^{18}$ Hearings on Study of Banking Laws, Financial Institutions Act of 1957, Before a Subcomm. of the Senate Comm. on Banking and Currency, 85th Cong., Ist Sess., pt. 2, at 779 (1957).

${ }^{10} 1 d$. at 788 .

${ }^{20} \mathrm{Id}$. at 525 .
} 
The restrictions of present law on the acquisition of additional capital by banks are not in our judgment reasonable. There are times, such as at present, when banks should have access to additional capital without total reliance on common stock. In some circumstances, preferred stock or debenture issues would offer a better and more feasible means of acquiring additional capital. Expansion of capital by this means is also advantageous for the reason that capital represented by such securities can be contracted by redemption or payment at any time that the additional capital represented by such securities is not needed in the business. The use of such securities, therefore, provides a flexible means of adjusting the capital requirements of banks to the needs of the times. ${ }^{21}$

Mr. Fleming also commented that the sale of common stock often diluted the equity of existing shareholders and that the use of debt securities would be of substantial benefit in allowing both large and small banks to increase their capital without such dilution. ${ }^{22}$

In spite of such arguments by bankers, state supervisory authorities-with the exception of those in New York and New Jersey-continued to subscribe to the views of the Comptroller of the Currency in refusing to allow the use of bank debentures in any but "emergency" or "distress" situations in which common stock could not be sold. Finally, in $195^{8}$, the state banking commissioner in Minnesota decided to permit the sale of subordinated debentures as a means by which a number of closely-held banks could raise their low capital ratios without risking loss of control by having to sell additional common stock. Several of these state-chartered banks have sold debentures in small issues ranging from $\$ 20,000$ to $\$ 200,000$.

The growing enthusiasm for bank debenture financing was reflected in the rg6I report of the Commission on Money and Credit. The Commission expressed concern regarding the capital adequacy of banking institutions and stated, "Two suggestions which should be explored are the authorization to issue debentures subordinated to the claims of the depositors and to issue preferred stock."23

In September 1962, the Advisory Committee on Banking to the Comptroller of the Currency (the "Saxon Committee"), after a comprehensive study of practices, policies, and problems of national banks, gave the most positive support of nonemergency debenture financing up to that time:

The practice has been to confine the issuance of preferred stock by National Banks to emergency situations. As a consequence, a widespread view has developed that the use of such stock by banks reflects a condition of financial difficulty. This view should be dispelled.

The use of preferred stock enables business firms to provide additional capital without diluting the equity position of the common shareholders. The use of debentures accomplishes the same result and has the additional advantage that interest costs are deductible for income tax purposes. There is no sound reason why

\footnotetext{
${ }^{21}$ Id. at 589 .

${ }^{22}$ Id. at 590 .

3s Commission on Money and Crebit, Money and Credit: Their Influence on Jobs, Pruces, and Growtr 174 (Report of the Comm'n on Money and Credit, 196r).
} 
National Banks should be deprived of any legitimate capital-raising method that is available to corporations generally. ${ }^{24}$

Soon after the above recommendation was made, the new Comptroller of the Currency, James J. Saxon, proposed new regulations officially authorizing the use of preferred stock as a normal means of raising new bank capital and allowing national banks to use capital debentures or notes in normal financing. ${ }^{25}$ The regulations applying to debentures are as follows:

(a) It is the policy of the Comptroller of the Currency to permit the issuance of convertible or nonconvertible capital debentures by national banking associations in accordance with normal business considerations.

(b) Subject to the provisions of I2 U.S.C. 82, the bank may, with the approval of stockholders owning two-thirds of the stock of the bank, entitled to vote, or without such approval if authorized by its Articles of Association, issue convertible or nonconvertible capital debentures in such amounts and under such terms and conditions as shall be approved by the Comptroller: Provided, however, That the principal amount of capital debentures outstanding at any time, when added to all other outstanding indebtedness of the bank, except those forms of indebtedness exempt from the provisions of I2 U.S.C. 82, shall not exceed an amount equal to Ioo percent of the bank's unimpaired paid-in capital stock plus $5^{\circ}$ percent of the amount of its unimpaired surplus fund..$^{26}$

Similar regulations permitted national banks to issue preferred stock in either convertible or nonconvertible forms in accordance with normal business conditions but did not limit issuance to roo per cent of capital stock plus fifty per cent of surplus, as in the case of the debt securities. ${ }^{27}$

Several state supervisory agencies promptly followed the lead of the Comptroller's office and authorized their state-chartered banks to issue senior securities in the course of normal operations. By June 1964 , all but fourteen states had authorized the use of debentures, and only four prohibited the use of both preferred stock and debentures. ${ }^{28}$

Many bankers and financial writers expressed enthusiasm regarding the 1962 authorization for issuance of senior securities, but it was not until September 1963 that the United California Bank of Los Angeles and the Franklin National Bank of Long Island initiated the new debenture trend by issuing by private placement $\$ 35$ million and $\$ 30$ million, respectively, of twenty-five-year capital debentures. ${ }^{20}$ During the latter part of $\mathrm{x}_{96} 6_{3}$, several other banks increased their capital funds via debentures to strengthen their risk asset ratios and restore their liquidity. The need for more capital arose from the stepped-up expansion of bank credit outstanding and

\footnotetext{
24 Advisory Committee on Banking, National Banks and the Future 82 (Report to the Comptroller of the Currency, 1962$)$.

${ }^{25} 27$ Fed. Reg. I022I (1962).

${ }^{26} 3$ I Fed. Reg. 6954 (I966).

27 Id.

${ }^{28}$ Bringhurst, Bank Debentures-\$500 Million Issued, Bankers MonthLy, June 1964, at 38 .

${ }^{20}$ Glore, Forgan \& Co., Commercial Bank Financing 2-4 (1963).
} 
related shifts in the composition of deposits and earning assets. ${ }^{30}$ Banks have favored debt securities over preferred stock principally because the interest on the former is tax deductible, which makes them a less expensive source of funds.

Since mid-rg63, debenture financing has been adopted enthusiastically by many commercial banks. Following the sale of nearly \$225 million of capital debentures in the second half of $I 963$, issuance of new debentures rose to over $\$ 640$ million in 1964 , and to more than $\$ 860$ million in 1965 . Due to pronounced tight money conditions in the first half of 1966 , new debenture sales slowed to less than $\$ 45$ million. ${ }^{31}$ By mid-Ig66, more than 200 banks, ranging in size from less than $\$ 25$ million of deposits to more than $\$ 5$ billion of deposits, had issued some $\$ 1.8$ billion of longterm debt securities.

\section{III}

\section{Evaluatton of the New SOURCES}

The new sources of commercial bank funds provided by negotiable certificates of deposit and subordinated debentures have developed relatively recently. While it may be too early to reach definitive conclusions regarding their contribution to the functioning of the money and capital markets, the experience with them certainly affords a basis for their tentative evaluation.

\section{A. Negotiable Certificates of Deposit}

\section{r. Benefits in the Money Market}

In the years since their emergence as a money market instrument, negotiable certificates of deposit have amply demonstrated their ability to attract and retain interest-sensitive funds of both business and other short-term investors, so long as banks are free to establish rates which are competitive with rates on other money market instruments. Thus the device of the certificate of deposit has delivered on its promise of enabling the commercial bank effectively to compete for funds. Most of the difficulties which have confronted commercial banks in this area have grown out of constraints imposed by Regulation $Q$. As with any form of regulatory intervention, price control in the certificate of deposit market has produced stresses and disruptions in the manner in which the market mechanism functions. In consequence, scarce capital resources may be misallocated, the patterns of investment distorted, and economic growth retarded.

Although still overshadowed by the immense volume of U.S. Treasury bills, certificates of deposit have emerged as the major money market instrument generated by the private sector of the economy. At peak levels in 1966, the \$18.2 billion of $\mathrm{C} / \mathrm{Ds}$ exceeded the total of finance company and commercial paper of \$13.0 billion and dwarfed bankers' acceptances of $\$ 3.4$ billion. Hence much of the resolution of

\footnotetext{
${ }^{80}$ Bankers and Their Borrowings, BaNK STock Q., June 1964, at 6.
}

${ }^{31}$ Capital Notes in Perspective, BanK Stock Q., June 1966, at 8. 
the forces of supply and demand has been worked out in the short-term money market in the rate on and volume of C/Ds.

Recent experience clearly demonstrates that the $\mathrm{C} / \mathrm{D}$ provides a mechanism that increases the efficiency of the money and capital markets in the allocation of scarce savings and that enhances the effectiveness of the monetary policy of the Federal Reserve in influencing the general level of economic activity. Unlike other financial intermediaries, commercial banks operate in virtually every sector of the money and capital markets. The large metropolitan banks, particularly, conduct their operations at the very heart of those markets. They serve as the focal point upon which money market pressures are brought to bear. Hence their untrammeled employment of the $C / D$ furnishes a remarkably apt channel for communicating these pressures throughout the financial system at the greatest possible speed. Through its function as the central private instrument reflecting the demand for and supply of short-term funds, the $\mathrm{C} / \mathrm{D}$ provides a device by which monetary policy can be diffused throughout the economy promptly and effectively. So long as commercial banks are free to compete in this market for the liquid funds of corporations, individuals, and governments, a means exists by which general monetary actions of the Federal Reserve can be transmitted quickly to those having excess funds as well as to those seeking to borrow funds. Through the $\mathrm{C} / \mathrm{D}$ the constraints of monetary stringency are distributed over the entire spectrum of the market with marginal pressures on many but with painful restrictions on the fewest possible.

C/Ds enhance the effectiveness of Federal Reserve control when monetary policy is directed toward influencing the cost and availability of credit to the economy as a whole. This is the proper objective of central banking management, and it is the goal to which the Federal Reserve has generally aspired.

In addition to their contribution to domestic money policy, certificates of deposit have served to mitigate the adverse balance of payments which has confronted the economy in the international sector. The introduction of these new instruments has attracted foreign deposits that might well otherwise have been withdrawn from the American market. While foreign private investors have not been aggressive purchasers of $\mathrm{C} / \mathrm{Ds}$, the certificate holdings of "foreign official institutions" have increased steadily since the suspension in October 1962 of Regulation $Q$ ceilings on such holdings. ${ }^{32}$ Holdings of foreign official institutions rose to about $\$ 4.8$ billion in mid-rg66 from about $\$ 2.4$ billion at weekly reporting member banks in leading cities at that time.

Experience over the past six years indicates that the imposition of ceiling rates on $\mathrm{C} / \mathrm{Ds}$ exposes the commercial banks and the Federal Reserve to the risk of periodic bouts of market distortions. Funds lodged in C/Ds are highly sensitive to interest rate differentials. As general interest rates rise during periods of business expansion,

\footnotetext{
${ }_{22}^{27}$ Fed. Reg. I025I (1962).
} 
banks bump up against rate ceilings and find themselves unable to attract new funds, or indeed to retain existing funds. In the face of rising loan demand and shrinking deposit volume, commercial banks are caught in a liquidity squeeze. These situations are likely to occur from time to time so long as the Federal Reserve continues to maintain ceilings on time deposits. Whereas suspension of Regulation $\mathrm{Q}$ or its relegation to standby status seems unlikely in the near future, the Federal Reserve may be expected to act to prevent major liquidity crises when significant disparities develop between Regulation $\mathrm{Q}$ ceilings and interest rates on competitive instruments in the free market. Until rates on time deposits are also free to follow general market rates, net losses of C/D funds to competing instruments seem likely to occur. These losses will cause setbacks to the secular growth of the certificate of deposit, but, more importantly, they will disrupt bank liquidity positions and risk disorder conditions in the money and capital markets.

While most of our experience with the $\mathrm{C} / \mathrm{D}$ has been during a period of rising business activity, loan demand, and interest rates, the instrument will perform a useful function in the declining stage of the business cycle as well. Slackening loan and investment demand would ease the pressure on banks to reach for additional deposit funds. This less aggressive promotion of new $\mathrm{C} / \mathrm{Ds}$ would tend to cause rates on them to fall, and this easing of interest rates and availability of funds would quickly be diffused throughout all segments of the money and capital markets.

\section{Potential Pitfalls for Issuing Banks}

It seems clear, also, as a result of experience with the $\mathrm{C} / \mathrm{D}$ thus far, that issuing banks must be careful in their employment of the instrument. Certain pitfalls may lie in the path. For example, during an upswing in business activity as firms' needs for cash mount, the ceilings on interest rates may prevent banks from offering sufficiently high rates to deter corporations from shifting funds from maturing $\mathrm{C} / \mathrm{Ds}$ into other forms. This may present a liquidity problem. Of course, certificates do bear specific maturity dates, so that banks are aware of the dates when such funds might be lost. However, because of the possible exposure to "hot money" flows, some banks, whose reputations are adequate to attract $\mathrm{C} / \mathrm{D}$ funds nationally, have been careful not to promote certificate sales to other than established customers in their primary banking market area.

Another possible piffall lies in the path of the use of the $C / D$ by smaller, inexperienced banks. Because the negotiable certificate is a prime money market instrument, it is a tool appropriate to the kit of the large money market bank. It frequently is not a useful device for the neighborhood bank. Since such "non-primename" banks must offer a higher yield on their certificates in periods of tight money, 
the ceiling rates restrain these smaller banks more quickly and more sharply than they do the large money market bank. Hence the impact of restraint imposed via Regulation $\mathrm{Q}$ is likely to fall first on small banks and, more importantly, on their small business customers rather than upon the large banks and their large corporate customers. Such a differential impact is inherent in price control policies such as Regulation Q.

To date, the most significant deterrent to the growth of the negotiable certificate of deposit as a banking instrument resulted from the adverse publicity engendered by the role of brokered certificate of deposit funds in the failure of a few small banks in 1964 and 1965.33 The high cost of acquiring brokered funds induced these banks to "reach unduly for income" by accepting greater risks. Furthermore, in some cases, the banks had not planned the maturity dates of the certificates and hence encountered substantial liquidity problems through the piling up of maturities. The largest of these banks had $\$ 40$ million in assets when it closed, on which C/D holders had claims of about $\$ 20$ million. Though the amounts of certificates involved were insignificant in the national market, the damage to the instrument's public image was felt in New York and other money markets, and certificates of deposit declined in popularity for a brief period.

This association of $\mathrm{C} / \mathrm{Ds}$ with banking difficulties, albeit in isolated instances, raised questions regarding federal control over certificate issuance. Defenders of the certificate of deposit assert, however, that the solvency situations which precipitated the failure of these banks was a consequence of management deficiencies rather than any shortcomings of the certificate device. Chairman Randall of the Federal Deposit Insurance Corporation has declared emphatically that "it is not C/Ds per se that create the problem-rather banks with improper intention." ${ }^{34}$ He has requested federal legislation to penalize improvident banks which violate Regulation $\mathrm{Q}$ and corresponding regulations of the FDIC. He proposed a penalty of perhaps ten per cent of the amount of deposits obtained through payment of fees or other compensation except as allowed by existing regulations. ${ }^{35}$

The $\mathrm{C} / \mathrm{D}$ is a sharp tool of bank management, and, as with any tool, its careless user can get hurt. Thus issuing banks must develop considerable expertise in the employment of the C/D. Quite apart from the effects of changes in legislation or regulatory directives, banks have had to give attention to maturity scheduling, have been forced to familiarize themselves with the patterns of the liquidity needs of their customers, and have had to strive constantly to tailor the maturities of the new certificates they sell to the banks' current needs for liquidity.

\footnotetext{
${ }^{33}$ See generally Silberman, Banking Backfire? Failures Spur Reaction Against Big Grosuth of Certificates of Deposit, Wall Street Journal, May 10, r965, at I, col. 6, for a discussion of some of the events and issues involved.

${ }^{84}$ Randall, Interest Rates and Regulations, American Banker, Oct. 5, 1965, at 16.

${ }^{35}$ ld.
} 
B. Subordinated Debentures

\section{Legal and Regulatory Deterrents to Their Use}

The difficulties of coping with Regulation $Q$ and the other uncertainties associated with $C / D$ banking impelled bankers to press for relaxation of restrictions on the issuance of debentures. However, despite the authorization granted to the issuance of senior securities, several legal and regulatory matters have remained as deterrents to their more rapid adoption.

Uncertainty as to whether debentures could be counted as capital for the purpose of establishing the lending limit for any one customer probably retarded the early adoption of nonemergency bank-debenture financing. However, the Comptroller of the Currency ruled on December 24, Ig63 as follows:

Under the terms of the aforesaid Capital Notes, the right of payment of principal and interest thereon is expressly subordinated to the prior payment in full of all deposit liabilities of the Bank. ... Capital Notes or Debentures so limited have all of the protective effect of capital and surplus insofar as depositors are involved. An examination of the legislative history of the lending restrictions contained in 12 U.S.C. 84 indicated that protection of depositors is the primary purpose of restricting the amount of loans to any person to a stated percentage of capital and surplus. Consequently, Capital Debentures and Notes which stand in the same relationship to depositors as traditionally unrecognized forms of capital and surplus may well be included in the loan base. ${ }^{36}$

Though this interpretation apparently settled the issue insofar as national banks are concerned, not all state banking authorities have followed the Comptroller's lead. Though most states now allow their banks to issue debt securities, a considerable number do not permit them to count debentures in determining the lending limit for a single customer. ${ }^{37}$

Moreover, the Board of Governors of the Federal Reserve System has still not accepted debentures as constituting bank "capital" for purposes of the provisions of the Federal Reserve Act. In Ig64, it ruled as follows:

A "note" or "debenture" is an evidence of debt, embodying a promise to pay a certain sum of money on a specified date. Such a debt instrument issued by a commercial bank is quite different from its "stock", which evidences a proprietary or "equity" interest in the assets of the bank. Likewise, the proceeds of a note or debenture that must be repaid on a specified date cannot reasonably be regarded as "surplus funds" of the issuing corporation. ...

Accordingly, under the law, capital notes or debentures do not constitute "capital", "capital stock", or "surplus" for the purposes of provisions of the Federal Reserve Act.... ${ }^{38}$

\footnotetext{
${ }^{\text {so }}$ I2 C.F.R. $\$ 7.7$ (Supp. I966).

${ }^{37}$ In mid-1964, 33 states did not include debentures in "capital" for loan-limit purposes; I9 of these did permit the issuance of debentures for the purpose of expanding bank capital under ordinary business conditions. See Bringhurst, supra note 28 , at 38 .

${ }^{38}$ 50 Fed. Reserve Bull. 9-10 (1964).
} 
This attitude of the Board does not substantially reduce the advantages of debentures, however, since the provisions of the Federal Reserve Act concerned with the size and composition of member bank capital are of limited importance insofar as the scope and flexibility of bank operations are concerned..$^{39}$

Another constraint on the growth of debenture financing has been provided by legal restrictions on their issuance. The limit for a national bank, as mentioned previously, is too per cent of the bank's unimpaired paid-in capital stock plus fifty per cent of its unimpaired surplus. Many states now have similar specific limits on a state bank's issuance of debentures. Most issuing banks have remained well within the limit in order to retain some latitude for debt financing in the future.40

\section{Development of Market Criteria}

Further limitations on banks' resort to debentures may be provided by evolving market standards regarding their issuance. The great majority of bank debenture issues have been privately placed; from 1963 through mid-Ig66, only twenty-four issues -the convertible and some nonconvertible issues-had been offered publicly. Nevertheless, market standards regarding investment in bank debentures are being developed. Since debentures are ordinarily subordinated to depositors' claims, banks in general would seem to be limited in their capacity to float additional debentures by market standards as to maximum acceptable ratios of deposits to debentures, debentures to total capital, and so forth. If the usual acceptable range of ratios for a given classification of banks is violated, interest costs for the bank in question, if not lack of market demand, might deter further debenture issuance. ${ }^{41}$ Bank conformity with market standards for minimum desired ratios of operating earnings to total fixed charges would also appear to be important. Then, too, such matters as a bank's recent loss experience, degree of diversification of its trade area, and degree of earnings stability may affect the market's qualitative evaluation of a bank's debentures. ${ }^{42}$

\footnotetext{
${ }^{30}$ See, e.g., Jessup, Bank Debt Capital: Urchin of Adversity to Child of Prosperity, Bankers MAOAzINE, Summer 1965 , at 40,45 .

${ }^{10}$ CE. Silverberg, Bank Borrowing: An Analysis of Recent Experience, 2 NaT' (1964). Sale and leaseback financing arrangements have bcen used by a considerable number of banks as an alternative to debenture financing to increase capital without any equity dilution for existing stockholders (hence, among other attributes, no sharing of voting control by the existing ownership group). Additional lendable and investable funds are provided the bank, as in the case of debenture financing. Since the real estate subsidiary or affiliate created to buy the bank's buildings and land in these situations-rather than the bank itself-issues the debt securities to effect the financing, the sale and leaseback arrangement enables the bank to conserve its own limited debenture-issuance capacity under existing regulations (and market standards) for use on other occasions. See GloRe, Forgan \& Co., stupra note 29, at I4-16.

12 With respect to investment market standards, it has been suggested that the capacity of small independent banks to finance with debentures could be increased if groups of such banks could arrange for pooled or package sales of debentures, so as to offer blecks of securities of a size and character which would have substantial market appeal. See Cates, Capital Tools for the Smaller Banks, BankErs MCNTHLY, Nov. 15, 1965, at 20.

4s Silverberg, supra note 40 , at 228.
} 


\section{Convertible Debentures}

Bank debentures may be issued in either convertible or nonconvertible form. By offering a convertible debenture, a bank may lower the yield rate by as much as one and a quarter to one and a half percentage points below what it otherwise would be. ${ }^{43}$ Convertible debt securities are a means of issuing common stock, that is, of making an addition to permanent capital, by indirection. Such financing is designed to cause less equity dilution than would occur through outright sale of common stock. To date, convertible debentures have been used much less frequently by banks than straight long-term debt securities. By mid-rg66 a dozen banks had sold some $\$ 353$ million of convertible debentures since 1963 . The figure is dominated by the 1965 issue by First National City Bank of New York of \$266 million of four per cent convertible debentures. This single issue represents seventy-six per cent of the dollar total for convertibles.

Unless a bank is seeking an expansion in its permanent capital base, it ordinarily would not consider a convertible debenture issue. Nonconvertible debentures bearing the call feature offer the issuing bank a means of bolstering capital position while avoiding dilution of control. Some strongly capitalized banks on the other hand have issued nonconvertible debentures apparently simply as a source of operating funds-as an alternative or supplement to "savings" deposits and relatively long-term "time" deposits. At times, debentures funds have appeared less expensive to some banks than time-deposit funds. ${ }^{44}$

\section{Short-term Notes}

An alternative source of operating funds was afforded by the short-term note. For a while, the relative attractiveness of debentures diminished with the innovation of short-term unsecured bank promissory notes. During 1963, Comptroller of the Currency Saxon sanctioned issuance of promissory notes of any maturity as part of ordinary bank financing. ${ }^{45}$ Notes of less than one-year maturity are directly

${ }^{13}$ Id. at 223; and see Capital Notes in Perspective, Bank Srock Q., June 1966, at 9, I2.

In the final analysis, the cost of convertible-debenture funds depends on the coupon rate and conversion price on the debentures, the bank's cost of equity capital, and the number of years before conversion takes place (assuming that it does). See Silverberg, Bank Debenture Financing: A Comparison of Alternatives, 3 Nat'l Banking Rev. 45, 49 (I965).

"P. S. Nadler, Time Deposits and Debentures: The New Sources of Bank Funds 24-27 (1964), contains a discussion of the relative profitability of debenture funds and time-deposit funds.

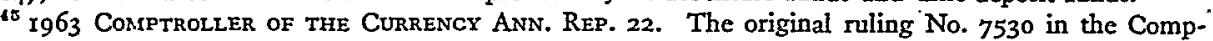
troller's manual stated that "A National Bank may sell at a discount or otherwise its own negotiable and nonnegotiable promissory notes of any maturity. Such borrowings are an essential part of the business of banking authorized by 12 U.S.C. 21 (par. 384 ) and 24 (par. 636; par. 640) and are recognized and limited by 12 U.S.C. 82 (par. 672). The proceeds from the sale of such notes do not constitute deposits and therefore the provisions of 12 U.S.C. 461 (par. 2072), 462 (par. 2076), and 1813 (par. 2408) relating to reserves, interest limitations, and deposit insurance are not applicable. ..." This ruling was amended as of June 1967 .

The revised rulings in the Comptroller's manual now state that "Ruling 7530, relating to issuance of promissory notes, has been amended to delete the provisions to the effect that a promissory note issued by a national bank in the regular course of business to obtain working funds for use in making loans was 
comparable with $\mathrm{C} / \mathrm{Ds}$ as a source of lendable and investable funds. Because of their short-dated maturities, they offer flexibility in the management of funds not possible with the longer-term debentures. Usually issued in unsubordinated form, the notes are not designed to alleviate any bank capital problems.

The note-derived funds originally had the advantages over $C / D$ funds of being free of reserve requirements, Regulation Q ceilings, and FDIC assessments. Shortterm notes were particularly valuable to banks as a potential means of attracting and/or retaining funds at times when Regulation $Q$ ceilings prevented effective competition by use of certificates of deposit. Late in 1965 , but before the December revision in Regulation $Q$, some large banks sold short-term promissory notes to alleviate liquidity strains. From time to time, First National Bank of Boston, First National Bank of Chicago, Continental Illinois National Bank, Irving Trust Company, Pittsburgh National Bank, Chase Manhattan Bank, and Philadelphia National Bank have all issued short-term notes to raise funds. Nevertheless, the aggregate amount of such notes outstanding has probably not exceeded $\$ 400$ million. ${ }^{40}$ This estimate does not include the very short maturity (usually 5-I 4 days) acknowledgments of advance issued for a brief period by such banks as Morgan Guaranty Trust Company and Chemical Bank New York Trust Company. In Janaury 1966, these amounted to about $\$ 50$ million, ${ }^{47}$ probably about one-eighth of the amount of short-term promissory notes then outstanding.

Issuance of short-term notes by national banks is limited by the same legal debt ceiling which applies to long-term debentures. Total indebtedness of a national bank, with the principal exception of borrowings from the Federal Reserve, is limited to the amount of capital stock and fifty per cent of surplus. Similar limitations on short-term note issuance by state banks exist in many states.

A study of note issuance by banks in the Boston Federal Reserve District revealed some interesting technical details which from the beginning impeded such issuance: (r) the Internal Revenue Service does not allow note proceeds to be invested in tax-exempt securities; and (2) local government units in New England are not permitted to invest in bank notes. ${ }^{48}$

Bankers' use of short-term notes was virtually terminated by the fact that, in September 1966, the Board of Governors of the Federal Reserve System classified short-term notes as deposits. ${ }^{49}$ This made them subject to the Board's reserve and interest-ceiling requirements. 'The banks' use of notes, the Board stated, had 'tended

excepted from the limitations of I2 U.S.C. 82 as to outstanding indebtedness, and did not constitute deposits for purposes of Regulations $Q$ and D."

16 This was the estimated amount outstanding at the time that the Federal Reserve announced plans to classify the short-term notes as deposits for reserve-requirement and intcrest-ceiling purposes (discussed in text accompanying notes 49-50 infra). See Hutnyan, Fed Plans to Put Promissory Notes Under Reserve, Interest Ceilings, American Banker, Jan. 21, 1966, at 1.

at $1 d$.

${ }^{4}$ Anderson, Short-Term Notes and Banking Competition, New England Bus. Rev., Dec. I964, at 7.

3 I Fed. Reg. 9103 (1966). 
to lessen the effectiveness of provisions of the Federal Reserve Act that prohibit the payment of interest on demand deposits, limit the rate of interest payable on time deposits and require reserves against deposits."

\section{Conclusion}

In the past few years commercial banks have developed two important new ways of competing for savings in the money and capital markets: negotiable certificates of deposit and subordinated debentures. In the five years after early Ig6r, C/D funds grew from just over $\$$ I.I billion to more than $\$$ I 8 billion. This volume, together with the very active secondary market which has developed, has made C/Ds the principal money market instrument issued by private institutions. Although the growth of subordinated debentures has not been as spectacular, they, too, offer promise of becoming a major means by which commercial banks can bid for funds. These new instruments contribute to the effective functioning of the nation's money markets by facilitating the flow of savings into investment. They enhance the operation of monetary policy by diffusing the impact of Federal Reserve actions promptly and efficiently through all segments of the money and capital markets. The role of the $C / D$, however, has been hampered by the Federal Reserve's Regulation $Q$, which acts as a price ceiling and limits the functioning of free money markets. Regulatory complexities also impose constraints on the use of subordinated debentures.

These new arenas for competition which the commercial banks have opened have great promise of benefiting the functioning of the money market and of the economy. They can best fulfill that promise if they are permitted a competitive footing equal to that of traditional money market instruments.

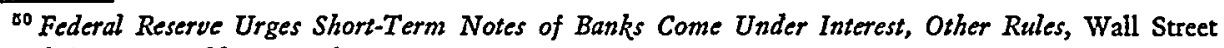
Journal, Jan. 2I, 1966, at 4, col. 2. 